\title{
CMC4 Gene
}

National Cancer Institute

\section{Source}

National Cancer Institute. CMC4 Gene. NCI Thesaurus. Code C84374.

This gene may be involved in the regulation of cellular proliferation. 